\title{
PEMETAAN ZONASI RAWAN BANJIR DENGAN ANALISIS INDEKS RAWAN BANJIR MENGGUNAKAN METODE FUZZY SIMPLE ADAPTIVE WEIGHTING
}

\author{
Yudi Setiawan ${ }^{1}$, Endina Putri Purwandari ${ }^{2}$, Andang Wijanarko ${ }^{3}$, Etis Sunandi ${ }^{4}$ \\ ${ }^{1,2,3}$ Program Studi Sistem Informasi, Fakultas Teknik, Universitas Bengkulu. \\ ${ }^{4}$ Program Studi Matematika, Fakultas Matematika dan Ilmu Pengetahuan Alam, Universitas Bengkulu \\ Jl. WR. Supratman Kandang Limun Bengkulu 38371A INDONESIA \\ (telp: 0736-341022; fax: 0736-341022) \\ ${ }^{1}$ ysetiawan@unib.ac.id, \\ endinaputri@unib.ac.id, \\ ${ }^{3}$ andangwijanarko@unib.ac.id \\ ${ }^{4}$ esunandi@unib.ac.id
}

Abstrak: Kota Bengkulu yang berbatasan dengan Samudera Hindia di sebelah barat, memiliki panjang garis pantai sepanjang tujuh kilometer. Pantai di Kota Bengkulu merupakan muara dua aliran sungai, yaitu; Sungai Bengkulu dan Sungai Jenggalu. Sungai-sungai tersebut sering terjadi luapan air hujan dari hulu sungai, yang berasal dari 5 kabupaten lainnya. Aktivitas di hulu sungai yang sudah tidak terkendali akibat aktivitas pertambangan dan perkebunan, mengakibatkan banjir khususnya yang terjadi di area sekitar Daerah Aliran Sungai (DAS) Sungai Bengkulu. Badan Nasional Penanggulangan Bencana Banjir telah menetapkan indeks bahaya banjir sebagai indikator batas ambang bencana banjir suatu wilayah. Indek bahaya banjir dapat digunakan sebagai kriteria pemetaan tingkat rawan banjir, dengan mengimplementasikan metode Fuzzy Simple Adaptive Weighting. Algoritma ini dapat memetakan dengan pemberian bobot setiap kriteria berdasarkan aturan normalisaisi. Proses klasifikasi pada penelitian ini dilakukan dengan mengimplementasikan metode Fuzzy Simple Adaptive Weighting ke dalam sistem pendukung keputusan (SPK). Analisis daerah banjir dengan metode Fuzzy Simple Adaptive Weighting, yang diharapkan dapat menentukan tingkat daerah rawan banjir, khususnya daerah yang berdampak pada pemukiman masyarakat dan fasilitas umum seperti jalan dan jembatan di sepanjang DAS Sungai Bengkulu. Hasil dari penelitian ini, yaitu; metode Fuzzy Simple Adaptive Weigting dapat memetakan tingkat rawan banjir dengan data set yang besar, dan hasil pemetaan didapatkan bahwa terdapat enam kelurahan yang harus mendapatkan prioritas penaggulangan banjir luapan DAS Sungai Bengkulu.

Kata kunci: Banjir, DAS Sungai Bengkulu, Fuzzy, Simple Adaptive Weigting.

Abstract: The city of Bengkulu, which borders the Indian Ocean to the west, has a coastline of seven kilometres. The beach in Bengkulu City is an estuary of two rivers, namely; Bengkulu River and Jenggalu River. The floods often rainwater overflows from the headwaters, which come from 5 other districts. Upstream activities which are out of control due to mining and plantation activities have caused flooding, especially in the area around the Bengkulu River Watershed. The National Flood Disaster Management Agency has established a flood hazard index as an indicator of a region's flood disaster threshold. Flood hazard index as a mapping criterion of flood level, by implementing the Fuzzy Simple Adaptive Weighting method. This algorithm can map by weighting each test based on normalization rules. The classification process in this study was carried out by implementing the Fuzzy Simple Adaptive Weighting method into the decision support system (SPK). Analysis of flood areas using the Fuzzy Simple Adaptive Weighting method, which is expected to determine the level of the flood-prone regions, especially areas that have an impact on community settlements and public facilities such as roads and bridges along the Bengkulu River Basin. The results of this study, namely; Fuzzy Simple Adaptive Weighing method can map the level of flood-prone with a large data set, and the results of the mapping found that three villages 
must get priority flood mitigation in the Bengkulu River watershed

Keywords: Flood, Bengkulu River Basin, Fuzzy, Simple Adaptive Weigting.

\section{PENDAHULUAN}

Kerusakan DAS Bengkulu semakin meningkat seiring dengan bertambahnya kegiatan pengambilan batubara secara terbuka pada wilayah hulu DAS Bengkulu dan pada kawasan Hutan Lindung Rindu Hati yang sudah diubah statusnya menjadi Hutan Produksi Tetap. Kondisi ini juga disebabkan tidak sinkronnya beberapa peraturan perundang-undangan terkait, dan implementasi otonomi daerah yang menekankan pada peningkatan PAD dan mengabaikan aspek keberlanjutan lingkungan; Konsep hukum pengelolaan tambang batubara berkelanjutan berdasarkan pendekatan DAS Bengkulu harus dibangun melalui Rencana Pengelolaan DAS Bengkulu, yang menetapkan zona hulu dan tengah DAS Bengkulu dengan sistem pertambangan tertutup (underground mining), sementara sistem pertambangan terbuka secara ketat dapat dilakukan di zona hilir DAS Bengkulu [1].

Dampak dari bencana banjir tersebut tidak hanya mengakibatkan kehilangan materi seperti kerusakan rumah, kehilangan harta benda, juga dampak dari banjir yang terjadi telah memakan korban nyawa yang dialami oleh tiga belas ribu warga Bengkulu. Selain berdampak pada warga Kota Bengkulu, banjir yang terjadi di Kota Bengkulu khususnya di wilayah DAS Sungai Bengkulu juga mengakibatkan kerusakan fasilitas umum, seperti jalan yang menjadi rusak dan rapuh untuk dilalui, jembatan, dan berbagai fasilitas umum lainnya.

Penelitian yang diusulkan dilakukan dengan beberapa tahapan berupa pengumpulan data pendukung analisis banjir di wilayah DAS Sungai
Bengkulu; Pengumpulan data topografi untuk proses pemodelan dampak banjir; melakukan analisis dampak banjir dengan metode Fuzzy Simple Adaptive Weighting; perancangan Sistem Pendukung Keputusan pemetaan tingkat daerah rawan banjir, dan pengumpulan data visualisasi tingkat daerah rawan bencana.

\section{TINJAUAN PUSTAKA}

\section{A. Daerah Aliran Sungai}

Daerah Aliran Sungai (DAS) secara umum didefinisikan sebagai suatu hamparan wilayah/ kawasan yang dibatasi oleh pembatas topografi (punggung bukit) yang menerima, mengumpulkan air hujan, sedimen dan unsur hara serta mengalirkannya melalui anak-anak sungai dan keluar pada sungai utama ke laut atau danau [2]. Menurut Linsley, 1980 DAS didefinisikan sebagai; " $A$ river of drainage basin in the entire area drained by a stream or system of connecting streams such that all stream flow originating in the area discharged through a single outlet”.

Prinsip transformasinya mengikuti 2 konsep dasar hidrologi yakni siklus hidrologi (hydrologic cycle) dan keseimbangan air (water balance). Respon DAS dalam mentransformasi aliran sangat tergantung dari beberapa hal, diantaranya curah hujan, kemiringan permukaan DAS, struktur dan sifat tanah, tingkat kejenuhan tanah dan faktor retensi aliran (vegetal cover). Empat faktor pertama sifatnya sangat alamiah sedangkan faktor yang terakhir sangat dipengaruhi oleh perilaku manusia dalam pengelolaan DAS (anthropogenic) [3].

\section{B. Banjir}

Bencana banjir merupakan salah satu bencana alam yang selalu terjadi di berbagai Wilayah Negara Kesatuan Republik Indonesia. Pengelolaan Sumber Daya Air (SDA) termasuk banjir tidak 
dapat dibatasi oleh wilayah administrasi, tetapi pengelolaan SDA dibatasi oleh Wilayah Sungai (WS). Wilayah Sungai ditetapkan dengan KEPPRES No. 12 Tahun 2012 tentang Penetapan Wilayah Sungai.

Banjir dapat disebabkan oleh kondisi alam yang statis seperti geografis, topografis, dan geometri alur sungai. Peristiwa alam yang dinamis seperti curah hujan yang tinggi, pembendungan dari laut/pasang pada sungai induk, amblesan tanah dan pendangkalan akibat sedimentasi, serta aktivitas manusia yang dinamis seperti adanya tata guna di lahan dataran banjir yang tidak sesuai, yaitu: dengan mendirikan pemukiman di bantaran sungai, kurangnya prasarana pengendalian banjir, amblesan permukaan tanah dan kenaikan muka air laut akibat global warming [4].

Banjir biasanya memiliki beberapa karakter: berbagai bencana lingkungan, sejumlah kecil daerah yang paling parah, awan dan hujan cuaca, dan perubahan cepat dalam bencana. Jadi, berbagai banjir pemantauan membutuhkan kemampuan data penginderaan jauh bersama dengan jangkauan luas, pencitraan semua cuaca pemantauan, dan resolusi spasial dan temporal yang tinggi [5].

\section{Data Spasial}

Data Spasial yang digunakan di dalam penelitian adalah data spasial yang bersumber dari Citra Landsat 8 dan foto udara dari Google Maps. Data-data spasial tersebut diolah dengan metode Fuzzy SAW untuk menghasilkan data analisis spasial. Server analisis model akan analisis pasokan model hidrologi (seperti model SCS), analisis statistik, analisis spasial, layanan peta web, web layanan fitur dan layanan geoproses untuk banjir perkiraan dan prediksi risiko banjir [6].

Landsat adalah deteksi dan pemantauan perubahan di permukaan bumi. Dengan menggabungkan secara digital dua atau lebih gambar yang dikumpulkan di area yang sama di permukaan bumi pada waktu yang berbeda dan menggunakan algoritma deteksi perubahan terkomputerisasi, pengguna dapat menganalisis perubahan objek di permukaan bumi [7].

\section{Fuzzy Simple Adaptive Weighting}

Fuzzy adalah suatu cara yang tepat untuk memetakan suatu ruang input ke dalam ruang output. Untuk sistem yang sangat rumit, penggunaan logika fuzzy (fuzzy logic) adalah salah satu pemecahannya. Sistem tradisional dirancang untuk mengontrol keluaran tunggal yang berasal dari beberapa masukan yang tidak saling berhubungan. Karena ketidaktergantungan ini, penambahan masukan yang baru akan memperumit proses kontrol dan membutuhkan proses perhitungan kembali dari semua fungsi. Kebalikannya, penambahan masukan baru pada sistem fuzzy, yaitu sistem yang bekerja berdasarkan prinsip-prinsip logika fuzzy, hanya membutuhkan penambahan fungsi keanggotaan yang baru dan aturan-aturan yang berhubungan dengannya.

Simple Additive Weighting (SAW) juga dikenal sebagai istilah pendekatan penjumlahan tertimbang. Konsep dasar SAW adalah untuk menemukan jumlah peringkat kinerja tertimbang pada setiap alternatif pada semua atribut. Metode SAW membutuhkan proses normalisasi hasil $\mathrm{X}$ dari sains yang dapat dibandingkan dengan semua peringkat alternatif yang tersedia [8]. Diagram alir metode Simple adaptive Weighting bekerja pada Gambar 1. 


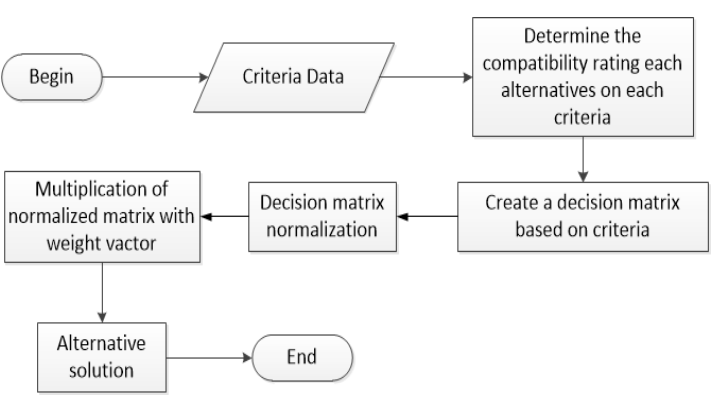

Gambar 1. Diagram Alir Metode Simple Adaptive Weigting [9]

Proses pembobotan adaptif sederhana dimulai dengan memasukkan data kriteria yang kemudian diproses untuk menentukan peringkat kompatibilitas setiap alternatif pada setiap kriteria untuk membuat keputusan matriks normalisasi dan kemudian memberikan solusi alternatif [9].

\section{METODE PENELITIAN}

Sistem Pendukung Keputusan (SPK) atau Decision Support System (DSS) adalah sebuah sistem yang mampu memberikan kemampuan pemecahan masalah maupun kemampuan pengkomunikasian untuk masalah dengan kondisi semi terstruktur dan tak terstruktur. Sistem ini digunakan untuk membantu pengambilan keputusan dalam situasi semi terstruktur dan situasi yang tidak terstruktur, dimana tak seorang pun tahu secara pasti bagaimana keputusan seharusnya dibat. SPK bertujuan untuk menyediakan informasi, membimbing, memberikan prediksi serta mengarahkan kepada pengguna informasi agar dapat melakukan pengambilan keputusan dengan lebih baik.

Proses penentuan klasifikasi tingkat rawan banjir dilakukan dari tahap analisis data indeks rawan banjir, berupa; tutupan lahan wilayah, topografi kemiringan wilayah, curah hujan wilayah, dan jarak tepi sungai terhdap pemukiman. Indeks yang dilakukan analisis berupa data lima tahun (2014-2018).
Kegiatan dimulai dari obeservasi/ studi lapangan untuk mengumpulkan data-data indikator penentuan tingkat rawan bencan banjir. Kemudian data-data tersebut dilakukan analisis dan diolah untuk digunakan pada Sistem Pendudkung Keputusan dengan mengimplementasikan metode Fuzzy Simple Adaptive Weighting yang akan dibangun nantinya. Sistem yang dibangun dapat melakukan pengolahan data non spasial dan data spasial yang bersumber dari observasi lapangan dan hasil pengolah citra landsat DAS Sungai Bengkulu 5 tahun terakhir.

Indikator-indikator penentuan wilayah tingkat rawan banjir diharapkan dapat melakukan (i) penetapan jalur banjir berdasarkan kekerapan yang pernah terjadi dan meneliti kondisi saluran air yang sudah ada, (ii) perkiraan kerugian akibat banjir dengan berbagai kekerapan dan mengembangkan catatan kekerapan banjir dan kerusakan yang ditimbulkan dengan basis tahunan, (iii) menelaah semua kemungkinan minimalisasi dampak banjir.

Data-data indeks rawan banjir yang didapatakan pada tahapan sebelumnya akan diolah dengan melakukan analisa penetuan tingkat rawan banjir dengan mengimplementasikan metode Fuzzy Simple Adaptive Weighting. Pada tahapan penelitian ini diharapkan menghasilkan nilai-nilai perubah yang nantinya dapat diklasisifikasikan untuk mendapatkan zonasi/ pemetaan wilayah tingkat rawan bencana banjir di sekitar wilayah DAS Sungai Bengkulu.

Perancangan Sistem Pendukung Keputusan (SPK) pada usulan penelitian ini dirancang berbasis web, dimana data spasial akan ditampilkan dalam bentuk peta. SIG analisi dan pemetaan tingkat rawan banjir di sekitar DAS Sungai Bengkulu dibangun dengan mengimplementasikan Fuzzy Simple Adaptive 
Weighting dalam penentuan daerah tingkat rawan bencana abrasi pantai.

Adapun data dan proses pemetaan tingkat rawan banjir dilakukan dengan proses; penentuan fuzzy, proses matrix normalisasi, proses matrix pembobotan, dan proses matrix clustering.

\section{HASIL DAN DISKUSI}

DAS Sungai Bengkulu melalui 2 wilayah kecamatan, yang meliputi sebelah utara sungai merupakan Kecamatan Muara Bangkahulu, dan sebelah selatan sungai merupakan wilayah Kecamatan Sungai Serut. DAS Sungai Bengkulu memotong wilayah Kota Bengkulu dari arah timur hingga bermuara di Samudera Hindia di sebelah Barat Kota Bengkulu. Adapun DAS Sungai Bengkulu ditunjukkan pada Gambar 2.

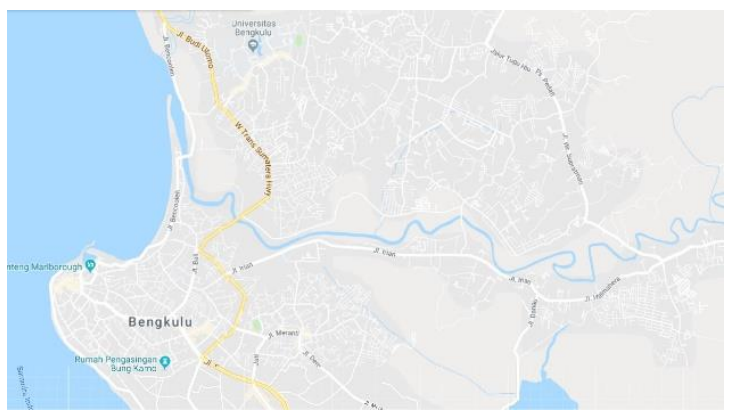

Gambar 2. DAS Sungai Bengkulu (Garis Sungai Bengkulu Memotong di Kota Bnegkulu)

Pada Kecamatan Muara Bangkahulu, wilayah yang berbatasan dengan tepi Sungai Bengkulu meliputi 6 wilayah kelurahan, yaitu; Rawa Makmur, Bentiring Permai, Bentiring, Pematang Gubernur, Kandang Limun, Beringin Raya. Adapun wilayah kelurahan di Kecamatan Sungai Serut yang berbatasan tepi Sungai Bengkulu meliputi 6 wilayah kelurahan, yaitu; Sukamerindu, Kampung Kelawi, Tanjung Agung, Tanjung Jaya, Semarang, Surabaya.
Indikator-indikator pada penelitian analisis penentuan tingkat wilayah rawan banjir di DAS Sungai Bengkulu, yaitu; (i) data tutupan lahan, (ii) ketinggian/ lereng wilayah, (iii) jarak pemukiman dari sungai, dan (iv) tingkat curah hujan. Indikatorindikator tersebut diolah secara spasial dan non spasial, yang kemudian menjadi parameterparameter dalam pengolahan klasifikasi dengan metode Fuzzy Simple Adaptive Weighting (SAW).

Kelas penutup lahan dibagi menjadi dua bagian besar, yaitu daerah vegetasi dan daerah tak bervegetasi. Semua kelas penutup lahan dalam kategori diturunkan dari pendekatan konseptual struktur fisiognomi yang konsisten dari bentuk tumbuhan, bentuk tutupan, tinggi tumbuhan. Sedangkan dalam kategori tak bervegetasi, pendetailan kelas mengacu pada aspek permukaan tutupan, distribusi atau kepadatan, dan ketinggian atau kedalaman obyek.

Kemiringan lereng merupakan faktor yang perlu diperhatikan, sejak dari penyiapan lahan pertanian, usaha penanamannya, pengambilan produk-produk serta pengawetan lahan. Lahan yang mempunyai kemiringan dapat lebih mudah terganggu atau rusak, lebih-lebih bila derajat kemiringannya besar. Garis sempadan pada sungai tidak bertanggul di dalam kawasan perkotaan dibagi dalam 3 kelas kategori $(10 \mathrm{~m}, 20 \mathrm{~m},>30$ $\mathrm{m})$. Curah hujan adalah jumlah air yang jatuh di permukaan tanah datar selama periode tertentu yang diukur dengan satuan tinggi milimeter ( $\mathrm{mm}$ ) di atas permukaan horizontal.

\section{E. Proses Fuzzy Data Lapangan}

Himpunan fuzzy merupakan perkembangan dari himpunan tegas. Himpunan tegas adalah himpunan yang nilai keanggotaan dari elemennya hanya mempunyai dua kemungkinan derajat keanggotaan yaitu; 
$\mu_{A}(x)=\left\{\begin{array}{c}1 ; j i k a x \in A \\ 0 ; j i k a x ! \epsilon A\end{array}\right.$

Keterangan:

$\mu_{A}$ adalah fungsi karakteristik dari himpunan.

Empat kriteria yang digunakan sebagai indeks tingkat rawan banjir pada penelitian dilakukan peneliana secara fuzzy. hal ini dilakukan untuk mengetahui derajad keabu-abuan nilai dari setiap data-data kriteria. Adapun hasil derajad keabuabuan dari data yang didapatkan, terdapat pada Tabel 1, sebagai berikut.

Table 1. Tabel Fuzzy Tutupan Lahan

\begin{tabular}{|c|c|c|c|c|c|c|c|c|}
\hline \multirow{2}{*}{ KELURAHAN } & \multicolumn{2}{|c|}{ Januari } & \multicolumn{2}{|c|}{ Februari } & \multicolumn{2}{|c|}{ Maret } & \multicolumn{2}{|c|}{ April } \\
\hline & Persentase & Nilai Fuzzy & Persentase & & Persentase & & Persentase & \\
\hline RAWAMAKMUR & 10,7 & 0,199255121 & 9,6 & 0,153354633 & 9,6 & 0,153354633 & 10,7 & 0,199255121 \\
\hline BENTIRING PERMAI & 40,9 & 0,761638734 & 16 & 0,255591054 & 16 & 0,255591054 & 40,9 & 0,761638734 \\
\hline BENTIRING & 43,2 & 0,804469274 & 42,2 & 0,674121406 & 42,2 & 0,674121406 & 43,2 & 0,804469274 \\
\hline PEMATANG GUBERNUR & 18,6 & 0,346368715 & 20,6 & 0,329073482 & 20,6 & 0,329073482 & 18,6 & 0,346368715 \\
\hline KANDANG LIMUN & 53,7 & 1 & 62,6 & 1 & 62,6 & 1 & 53,7 & 1 \\
\hline BERINGIN RAYA & 47,6 & 0,886405959 & 53 & 0,846645367 & 53 & 0,846645367 & 47,6 & 0,886405959 \\
\hline PASAR BENGKULU & 46,6 & 0,867783985 & 55,1 & 0,880191693 & 55,1 & 0,880191693 & 46,6 & 0,867783985 \\
\hline KAMPUNG KELAWI & 10,4 & 0,193668529 & 11,2 & 0,178913738 & 11,2 & 0,178913738 & 10,4 & 0,193668529 \\
\hline SUKAMERINDU & 12,1 & 0,225325885 & 10,2 & 0,162939297 & 10,2 & 0,162939297 & 12,1 & 0,225325885 \\
\hline TANJUNG AGUNG & 19,1 & 0,355679702 & 11,8 & 0,188498403 & 11,8 & 0,188498403 & 19,1 & 0,355679702 \\
\hline TANJUNG JAYA & 34,2 & 0,636871508 & 12,7 & 0,202875399 & 12,7 & 0,202875399 & 34,2 & 0,636871508 \\
\hline SEMARANG & 23 & 0,4283054 & 14 & 0,223642173 & 14 & 0,223642173 & 23 & 0,4283054 \\
\hline \multirow[t]{3}{*}{ URABAYA } & 44,6 & 0,830540037 & 35,1 & 0,560702875 & 35,1 & 0,560702875 & 44,6 & 0,830540037 \\
\hline & 0 & 53,7 & 0 & 62,6 & 0 & 62,6 & 0 & 53,7 \\
\hline & MIN & MAX & MIN & MAX & MIN & MAX & MIN & MAX \\
\hline
\end{tabular}

Pada Table 1 merupakan nilai tutupan lahan yang didapatkan dari spasial analisis, yang kemudian dilakukan proses fuzzy untuk mendapatkan nilai derajat keabu-abuan. Hal ini juga dilakukan pada parameter topografi, curah hujan, dan jarak tepi sungai ke pemukiman.

\section{F. Matrix Normalisasi}

Metode SAW membutuhkan proses normalisasi matriks keputusan $x$ ke suatu skala yang dapat diperbandingkan dengan semua rating alternatif yang ada. Adapun kriteria yang menjadi kriteria benefit, yaitu; kriteria tutupan lahan, dan kriteria topografi. Sedangkan kriteria cost, yaitu; kriteria curah hujan dan kriteria jarak tepi sungai terhadap pemukiman. Proses matrix normalisasi dilakukan dengan persamaan (2).

$r_{i j}=\left\{\begin{array}{l}\frac{x_{i j}}{\operatorname{Max}_{i} x_{i j}} \text { jika } j \text { adalah atribut benefit } \\ \frac{\operatorname{Min}_{i} x_{i j}}{x_{i j}} \text { jika } j \text { adalah atribut cost }\end{array}\right.$

Adapun hasil dari nilai fuzzy dari empat parameter, dimasukkan ke dalam matrix normalisasi, ditunjukkan pada Tabel 2, sebagai berikut; 
Table 2. Matrix Normalisai Parameter-Parameter Rawan Banjir

\begin{tabular}{|c|c|c|c|c|c|c|}
\hline \multicolumn{3}{|c|}{ Kandidat } & \multicolumn{4}{|c|}{ Kriteria } \\
\hline Kelurahan & Bulan & Tahun & Tutupan Lahan) & C2 (Curah Hujan) & C3 (Topografi) & C4 (Jarak Pemukiman <10 M) \\
\hline 1 RAWA MAKMUR & Januari & 2014 & 0,011637804 & 0,140237325 & 0,998317442 & 0,001322084 \\
\hline 2 BENTIRING PERMAI & Januari & 2014 & 0,04448469 & 0,140237325 & 0,720699071 & 1 \\
\hline 3 BENTIRING & Januari & 2014 & 0,046986274 & 0,140237325 & 0,530126336 & 0,004342626 \\
\hline 4 PEMATANG GUBERNU & R Januari & 2014 & 0,020230202 & 0,140237325 & 0,825423105 & 1 \\
\hline 5 KANDANG LIMUN & Januari & 2014 & 0,05840655 & 0,140237325 & 0,98681442 & 1 \\
\hline 6 BERINGIN RAYA & Januari & 2014 & 0,051771914 & 0,140237325 & 0,993230769 & 1 \\
\hline 7 PASAR BENGKULU & Januari & 2014 & 0,050684268 & 0,31026253 & 1 & 0,001625251 \\
\hline 8 KAMPUNG KELAWI & Januari & 2014 & 0,011311511 & 0,31026253 & 0,983682984 & 0,008540146 \\
\hline 9 SUKAMERINDU & Januari & 2014 & 0,013160507 & 0,31026253 & 0,955527319 & 1 \\
\hline 10 TANJUNG AGUNG & Januari & 2014 & 0,020774024 & 0,31026253 & 1 & \\
\hline 11 TANJUNG JAYA & Januari & 2014 & 0,037197467 & 0,31026253 & 1 & 1 \\
\hline 12 SEMARANG & Januari & 2014 & 0,025015841 & 0,31026253 & 1 & 0,001 \\
\hline 13 SURABAYA & Januari & 2014 & 0,048508978 & 0,31026253 & 0,954972786 & 0,007228668 \\
\hline
\end{tabular}

\section{G. Matrix Pembobotan}

Matriks keputusan dinormalisasi menjadi matriks ternormalisasi, berikutnya adalah mengalikan nilai baris matriks ternormalisasi $\left(r_{i j}\right)$ dengan bobot tiap kriterianya $\left(\mathrm{w}_{\mathrm{ij}}\right)$. Adapun proses dinormalisasi dengan persamaan (3).

$$
A_{i j}=r_{i j} x w_{i j}
$$

Adapun nilai pembobotan yang digunakan pada penelitian ini, ditunjukkan pada Tabel 3, sbeagi berikut;
Table 3. Matrik Pembobotan Tingkat rawan Banjir Berdasarkan Pedoman Risiko Bencana Indonesia (RBI)

\begin{tabular}{|c|c|c|}
\hline No & \multicolumn{1}{|c|}{ Kriteria } & Pembobotan \\
1 & C1 (Tutupan Lahan) & 0,8 \\
2 & C2 (Curah Hujan) & 0,3 \\
\hline 3 & C3 (Topografi) & 0,8 \\
\hline 4 & C4 (Jarak Pemukiman <10 M) & 1 \\
\cline { 2 - 3 } & Jumlah Pembobotan & $\mathbf{2 , 9}$ \\
\cline { 2 - 3 } & Min Jumlah Pembobotan & $\mathbf{0 , 0 0 0 1}$ \\
\hline
\end{tabular}

Adapun hasil dari hasil matrix pembobotan yang didapatkan berdasarkan Persamaan 3 terdapat pada Tabel 4, sebagai berikut;

Table 4. Matrix Pembobotan Parameter Tingkat Rawan Banjir

\begin{tabular}{|c|c|c|c|c|c|c|c|}
\hline \multicolumn{3}{|c|}{ Kandidat } & \multicolumn{4}{|c|}{ Kriteria } & \multirow[b]{2}{*}{ Jumlah } \\
\hline Kelurahan & Bulan & Tahun & utupan Lahan) & C2 (Curah Hujan) & C3 (Topografi) & C4 (Jarak Pemukiman <10 M) & \\
\hline 1 RAWA MAKMUR & Januari & 2014 & 0,009310243 & 0,042071197 & 0,798653954 & 0,001322084 & 0,851357 \\
\hline 2 BENTIRING PERMAI & Januari & 2014 & 0,035587752 & 0,042071197 & 0,576559257 & 1 & 1,654218 \\
\hline 3 BENTIRING & Januari & 2014 & 0,03758902 & 0,042071197 & 0,424101069 & 0,004342626 & 0,508104 \\
\hline 4 PEMATANG GUBERNUR & Januari & 2014 & 0,016184161 & 0,042071197 & 0,660338484 & 1 & 1,718594 \\
\hline 5 KANDANG LIMUN & Januari & 2014 & 0,04672524 & 0,042071197 & 0,789451536 & 1 & 1,878248 \\
\hline 6 BERINGIN RAYA & Januari & 2014 & 0,041417531 & 0,042071197 & 0,794584615 & 1 & 1,878073 \\
\hline 7 PASAR BENGKULU & Januari & 2014 & 0,040547415 & 0,093078759 & 0,8 & 0,001625251 & 0,935251 \\
\hline 8 KAMPUNG KELAWI & Januari & 2014 & 0,009049208 & 0,093078759 & 0,786946387 & 0,008540146 & 0,897615 \\
\hline 9 SUKAMERINDU & Januari & 2014 & 0,010528406 & 0,093078759 & 0,764421855 & 1 & 1,868029 \\
\hline 10 TANJUNG AGUNG & Januari & 2014 & 0,016619219 & 0,093078759 & 0,8 & 1 & 1,909698 \\
\hline 11 TANJUNG JAYA & Januari & 2014 & 0,029757974 & 0,093078759 & 0,8 & 1 & 1,922837 \\
\hline 12 SEMARANG & Januari & 2014 & 0,020012672 & 0,093078759 & 0,8 & 0,001 & 0,914091 \\
\hline 13 SURABAYA & Januari & 2014 & 0,038807182 & 0,093078759 & 0,763978229 & 0,007228668 & 0,903093 \\
\hline
\end{tabular}

\section{H. Matrix Clustering}

Clusterring pada penentuan tingkat rawan banjir, dilakukan dengan pengelompokkan berdasarkan lima tingkatan, dengan penentuan berdasarkan nilai maksimum dan minimum. Adapun clustering yang dilakukan berdasarkan Tabel 5, sebagai berikut;
Table 5. Nilai Clusterring Zona Kerentanan Rawan Banjir

\begin{tabular}{|l|r|}
\hline No Zona Kerentanan Rawan Banjir & \multicolumn{2}{c|}{ Range } \\
1 Sangat Rendah & $2,9-2,3201$ \\
2 Rendah & $2,32-1,7401$ \\
3 Sedang & $1,74-1,1601$ \\
4 Tinggi & $1,16-0,5801$ \\
5 Sangat Tinggi & $0,58-0,0001$ \\
\hline
\end{tabular}

Berdasarkan nilai clustering pada Tabel 5, maka didapatkan nilai cluster dari setiap kelurahan, ditunjukkan pada Tabel 6, sebagi berikut; 
Table 6. Tingkat Rawan Banjir Hasil Perhitungan dengan Metode Fuzzy SAW

\begin{tabular}{|c|c|c|c|c|c|c|c|c|c|}
\hline \multicolumn{4}{|c|}{ Kandidat } & \multicolumn{4}{|c|}{ Kriteria } & \multirow[b]{2}{*}{ Jumlah } & \multirow[b]{2}{*}{ Clusterring } \\
\hline No & Kelurahan & Bulan & Tahun & Tutupan Lahan) $\mathrm{C}$ & C2 (Curah Hujan) & ) C3 (Topografi) & $\mathrm{C4}$ (Jarak Pemukiman <10 M) & & \\
\hline \multicolumn{2}{|c|}{1 RAWA MAKMUR } & Januari & 2014 & 0,009310243 & 0,042071197 & 0,798653954 & 0,001322084 & 0,851357 & Tinggi \\
\hline \multicolumn{2}{|c|}{2 BENTIRING PERMAI } & Januari & 2014 & 0,035587752 & 0,042071197 & 0,576559257 & 1 & 1,654218 & Sedang \\
\hline \multicolumn{2}{|c|}{3 BENTIRING } & Januari & 2014 & 0,03758902 & 0,042071197 & 0,424101069 & 0,004342626 & 0,50810 & Sangat Tingg \\
\hline \multicolumn{3}{|c|}{4 PEMATANG GUBERNUR Januari } & 2014 & 0,016184161 & 0,042071197 & 0,660338484 & 1 & 1,71859 & Sedang \\
\hline \multicolumn{2}{|c|}{5 KANDANG LIMUN } & Januari & 2014 & 0,04672524 & 0,042071197 & 0,789451536 & 1 & 1,878248 & Rendah \\
\hline \multicolumn{2}{|c|}{6 BERINGIN RAYA } & Januari & 2014 & 0,041417531 & 0,042071197 & 0,794584615 & 1 & 1,878073 & Rendah \\
\hline \multicolumn{2}{|c|}{7 PASAR BENGKULU } & Januari & 2014 & 0,040547415 & 0,093078759 & 0,8 & 0,001625251 & 0,93525 & Tinggi \\
\hline \multicolumn{2}{|c|}{8 KAMPUNG KELAWI } & Januari & 2014 & 0,009049208 & 0,093078759 & 0,786946387 & 0,008540146 & 0,897615 & Tinggi \\
\hline \multicolumn{2}{|c|}{9 SUKAMERINDU } & Januari & 2014 & 0,010528406 & 0,093078759 & 0,764421855 & 1 & 1,868029 & Rendah \\
\hline \multicolumn{2}{|c|}{10 TANJUNG AGUNG } & Januari & 2014 & 0,016619219 & 0,093078759 & 0,8 & 1 & 1,909698 & Rendah \\
\hline \multicolumn{2}{|c|}{11 TANJUNG JAYA } & Januari & 2014 & 0,029757974 & 0,093078759 & 0,8 & 1 & 1,922837 & Rendah \\
\hline \multicolumn{2}{|c|}{12 SEMARANG } & Januari & 2014 & 0,020012672 & 0,093078759 & 0,8 & 0,001 & 0,914091 & Tinggi \\
\hline \multicolumn{2}{|c|}{13 SURABAYA } & Januari & 2014 & 0,038807182 & 0,093078759 & 0,763978229 & 0,007228668 & 0,903093 & Tinggi \\
\hline
\end{tabular}

\section{Pemetaan Tingkat Rawan Banjir}

Berdasarkan perhitungan hasil penilaian Fuzzy Simple Adaptive Weighting (Tabel 6) dilakukan proses clustering untuk selama 5 tahun terakhir, dengan perubahan yang terjadi pada Tahun 2014 dan pada Tahun 2018. Perubahan tingkat rawan banjir setiap bulannya pada Tahun 2014 pada Gambar 3 dan Tahun 2018 ditunjukkan Gambar 4, sebagai berikut;

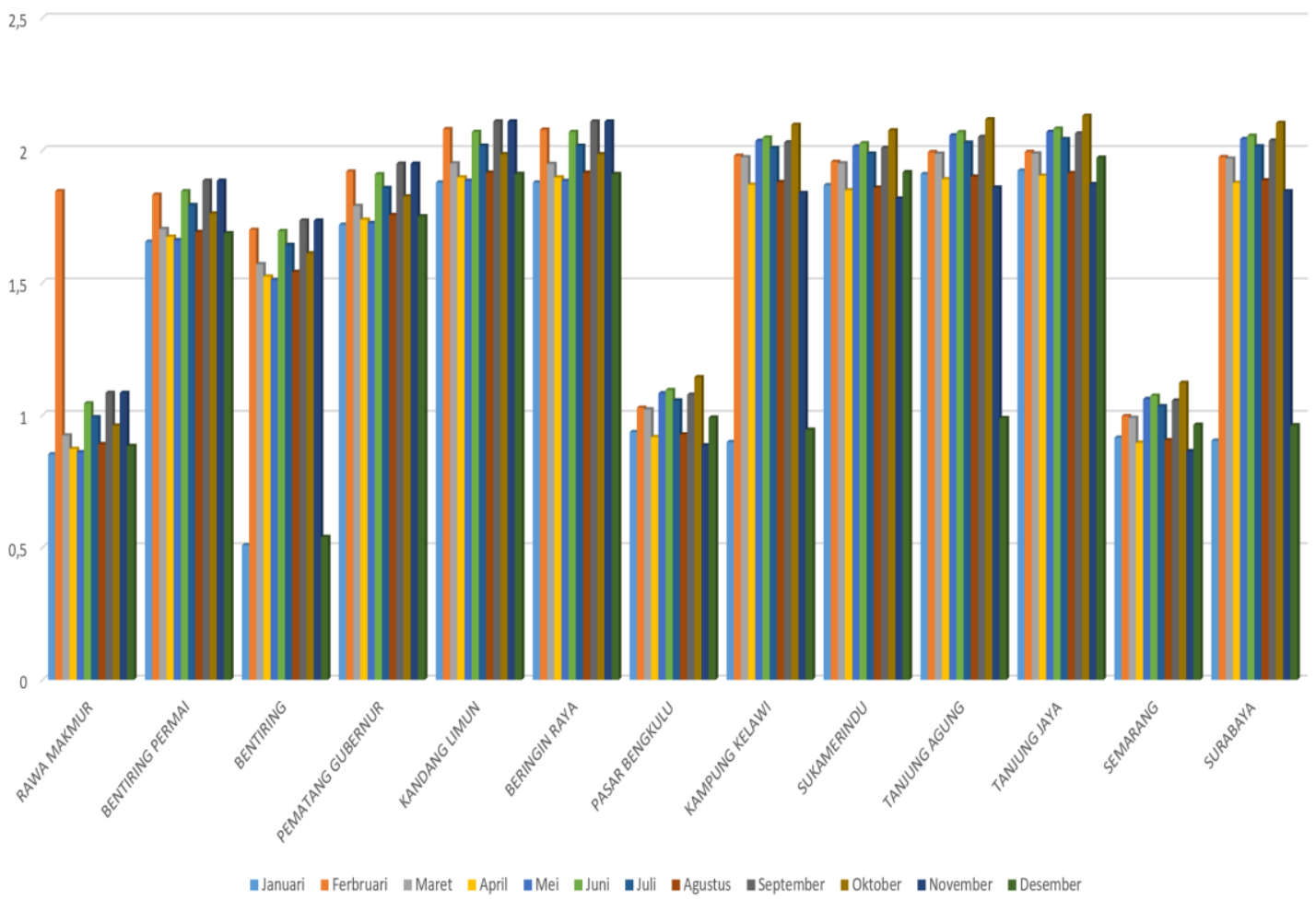

Gambar 3. Hasil Perhitungan Fuzzy SAW pada Tingkat Rawan Banjir Tahun 2014 


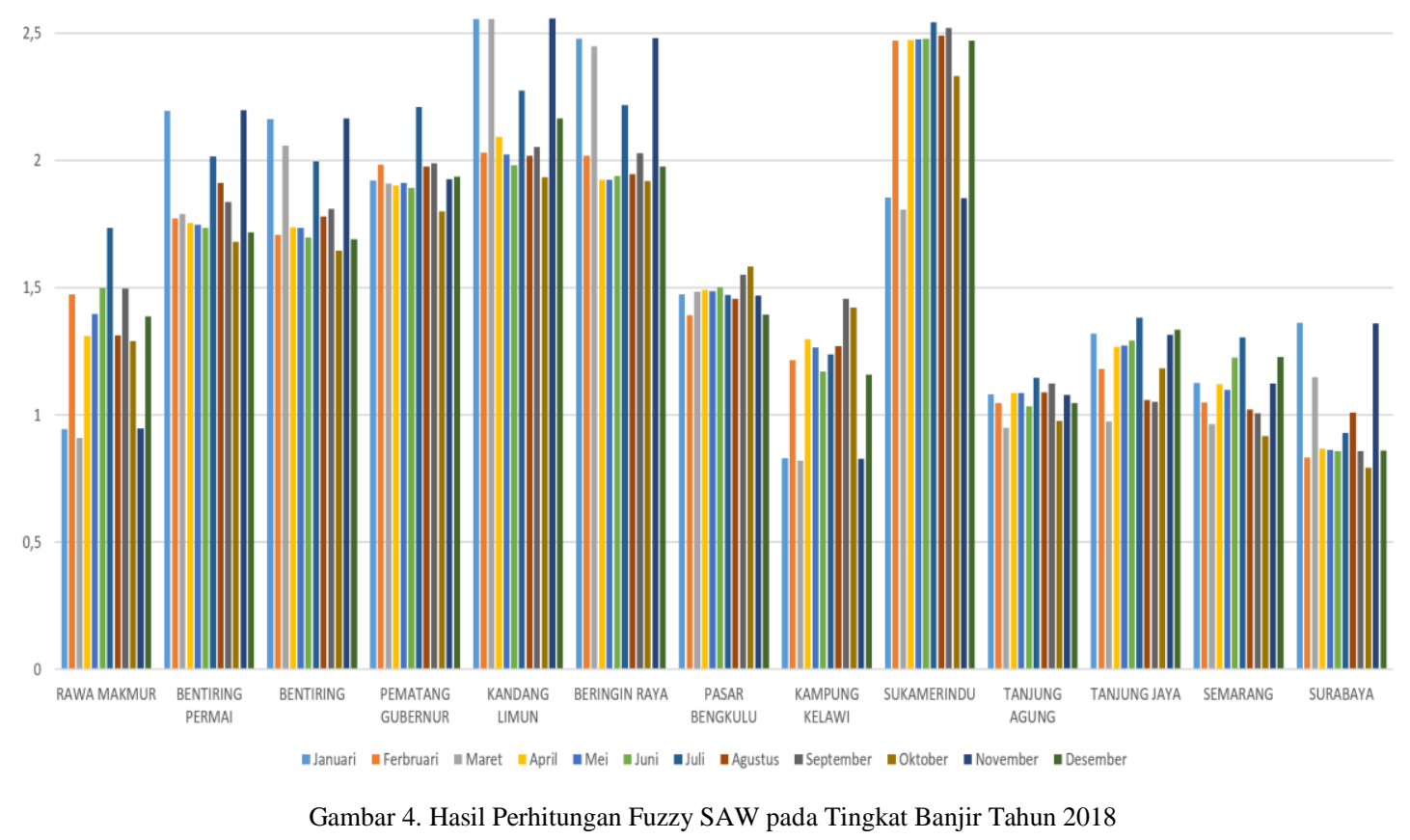

Pada Gambar 3 menunjukkan bahwa semakin kecil nilai perhitungan Fuzzy Simple Adaptive, maka semakin tinggi tingkat rawan banjir pada Tahun 2014. Berdasarkan data spasial (tutupan lahan, topografi, dan jarak tepi sungai ke pemukiman) dan data non-spasial (curah hujan) sepanjang Tahun 2014, didaptkan bahwa terdapat empat kelurahan yang memiliki cluster tingkat rawan bencana banjir sangat tinggi, yaitu; Kelurahan Rawa Makmur, Pasar Bengkulu, dan Semarang. Akan tetapi pada Kelurahan Rawa Makmur, Bentiring, Kampung Kelawi, dan Surabay terdapat perubahan tingkat rawan banjir yang sangat berbeda di beberapa bulan tertentu, hal ini dikarenakan perubahan yang signifikan terjadi di beberapa parameter tingkat rawan banjir.

Pada Gambar 4 menunjukkan bahwa pada Tahun 2018 terdapat peningkatan rawan banjir untuk enam kelurahan. Hal ini terjadi sangat signifikan dibandingkan dengan data yang terjadi pada Tahun 2014. Kelurahan yang memiliki tingkat rawan banjir yang tinggi, yaitu; Kelurahan Rawa Makmur, Kampung Kelawi, Tanjung Agung, Tanjung Jaya, Semarang, dan Surabaya.
Pada tahun 2018 terdapat satu kelurahan yang memiliki risiko rawan banjir yang dapat berubahubah sewaktu-waktu, yaitu; Kelurahan Sukamerindu.

Berdasarkan hasil dari perhitungan Fuzzy Simple Adaptive Weighting guna memetakan tingkat rawan banjir, maka terdapat beberapa kelurahan yang memiliki batas tepi dengan DAS Sungai Bengkulu yang hendaknya memiliki kebijakan prioritas dalam pengelolaan pemukiman di sepanjang DAS.

\section{KESIMPULAN}

Fuzzy Simple Adaptive Weighting dapat digunakn untuk melakukan pemetaan clustering tingkat rawan banjir di sepanjang Daerah Aliran Sungai Bengkulu, di Kota Bengkulu. Pada perhitugan Fuzzy SAW menggunakan empat parameter yang menjadi atribut Fuzzy SAW, yaitu; data spasial tutupan lahan, data spasial topografi, dan data spasial jarak tepi sungai terhadap pemukiman, dan data non spasial berupa data curah hujan sepanjang tahun. 
Berdasarkan data selama lima tahun (20142018) terdapat enam kelurahan yang dapat memiliki prioritas kebijakan penanganan dan penaatan wilayah DAS Sungai Bengkulu, yaitu: Kelurahan Rawa Makmur, Kampung Kelawi, Tanjung Agung, Tanjung Jaya, Semarang, dan Surabaya. Enam kelurahan tersebut sejak Tahun 2014 terus mengalami peningkatan tingkat rawan banjir.

\section{UCAPAN TERIMA KASIH}

Penulis ingin mengucapkan terima kasih kepada Lembaga Penelitian dan Pengabdian Kepada Masyarakat Universitas Bengkulu yang telah membantu dukungan pendanaan, dan telah memberikan dukungan berupa pelatihan dan workshop sehingga penulis telah mampu menyelesaikan kegiatan ini.

\section{REFERENSI}

[1] E. Satmaidi, A. A. Muthia, and Wulandari, "Konsep Hukum Pengelolaan Tambang Batubara Berkelanjutan Berdasarkan Pendekatan Daerah Aliran Sungai (Das) Di Provinsi Bengkulu," Bina Huk. Lingkung., vol. 2, no. 2, Apr. 2018.

[2] Direktorat Kehutanan dan Konservasi Sumberdaya Air, "KAJIAN MODEL PENGELOLAAN DAERAH
ALIRAN SUNGAI (DAS) TERPADU.” Bappenas RI, 2008.

[3] I. G. Tunas, "PREDIKSI EROSI LAHAN DAS BENGKULU DENGAN SISTEM INFORMASI GEOGRAFIS (SIG)," J. Smartek, vol. Vol 3, no. Nomor 3, pp. 137-145, 2005.

[4] M. R. Amri, G. Yulianti, R. Yunus, and S. Wiguna, Risiko Bencana Indonesia (RBI). BNPB Indonesia, 2016.

[5] W. Zheng, "The flood monitoring information system framework based on multi-source satellite remote sensing data," in 2012 International Conference on System Science and Engineering (ICSSE), 2012, pp. 306-309.

[6] Lei Wang and Qiuming Cheng, "Design and implementation of a web-based spatial decision support system for flood forecasting and flood risk mapping," in 2007 IEEE International Geoscience and Remote Sensing Symposium, 2007, pp. 4588-4591.

[7] G. Sitanggang, "Kajian Pemanfaatan Satelit Masa Depan: Sistem Penginderaan Jauh Satelit Ldcm (Landsat-8)," J. Lapan, vol. 11, no. 2, Jun. 2010.

[8] S. Kusumadewi, S. Hartati, A. Harjoko, and R. Wardoyo, Fuzzy Multi-Attribute Decision Making (FUZZY MADM). Yogyakarta: Penerbit Graha Ilmu, 2006.

[9] Y. Setiawan, B. Susilo, A. Erlanshari, F. Sumitra, and E. Maryanti, "Design and Implementation of the Culinary Recommendation System Using Sentiment Analysis and Simple Adaptive Weighting in Bengkulu, Indonesia," Proceeding 5th Int. Conf. Electr. Eng. Comput. Sci. Inform. EECSI 2018, vol. 5, pp. 603-607, 2018. 